\title{
The Persistent Memory of Historic Wrongs in China: A Discussion of Demands for "Reappraisal"
}

\section{Eva Pils}

\section{(2) OpenEdition}

12 Journals

Édition électronique

URL : http://journals.openedition.org/chinaperspectives/2633

DOI : $10.4000 /$ chinaperspectives.2633

ISSN : 1996-4617

Éditeur

Centre d'étude français sur la Chine contemporaine

\section{Édition imprimée}

Date de publication : 15 décembre 2007

ISSN : 2070-3449

Référence électronique

Eva Pils, « The Persistent Memory of Historic Wrongs in China: A Discussion of Demands for "Reappraisal" ", China Perspectives [En ligne], 2007/4 | 2007, mis en ligne le 30 décembre 2010, consulté le 28 octobre 2019. URL : http://journals.openedition.org/chinaperspectives/2633 ; DOI : 10.4000/chinaperspectives.2633 


\title{
The Persistent Memory of
}

\section{Historic Wrongs in China}

\author{
A Discussion of Demands for "Reappraisal"
}

EVA PILS*

This essay describes two forms of institutional redress for historic wrongs in contemporary China, arguing that one is authoritarian, the other liberal, and that neither is entirely satisfactory. Some victims of political persecution reject the right of the state to classify citizens as enemies, and with it the authoritarian method of corrective official reappraisal. Liberal avenues of redress through adjudication, on the other hand, remain closed to most victims of historic injustice, and are meaningful only if accompanied by the liberation of memory and opinion.

"What the Chinese authorities are most afraid of now is that the people should have memories." ${ }^{(1)}$

I n June 2007, the Chengdu Evening News carried a tiny advertisement, a single line containing 13 characters. It read, "Paying tribute to the strong mothers of the June $4^{\text {th }}$ victims!" (2) According to later reports, the sub-editor in charge of advertisements, who was only 18 , had not recognized "June $4^{\text {th}}$ " as a politically sensitive reference to the date of the suppression of protests on and near Tiananmen Square in Beijing and elsewhere, 4 June 1989, and had therefore failed to reject the ad. His 21-year-old colleague had surmised that the date might refer to a local mine disaster. Both young men and at least one other editor were fired for their lapse. ${ }^{(3)}$ The person who had placed the advertisement was quickly identified and subjected to six months of criminal investigation under surveillance on suspicion of state subversion. ${ }^{(4)}$

The fact that an urban youth working as a newspaper sub-editor could fail to recognize the traumatic date of "6-4" shows that the government has had some success in its singleminded effort to suppress the memory of this event. Indeed, pictures that we call "iconic," such as that of the June $4^{\text {th }}$ "tank man," may elicit no recognition at all amongst young Chinese university students. ${ }^{(5)}$ Individuals with relevant personal experiences have never been allowed to exchange, compare, and challenge their memories in public in a way that would allow for these individual recollections to become part of a shared history. In China, as opposed to overseas, no collective memory of the event has been created.

Even so, a contentious issue remains: should the party-state's verdict on June $4^{\text {th }}$ be reversed? Should the protesters of 1989 be rehabilitated? And should other victims of political criminalization - for instance, victims of the Anti-Rightist campaigns, of the suppression of Democracy Wall writers, etc. - be rehabilitated as well? The political and legal parameters of this discussion have changed since 1989, with an increasing number of calls for redress in a great variety of other cases of conflict between citizens and party-state au-

I thank Stephen Guest and Yu Xingzhong for their helpful comments on this paper.

1. Tie Liu, "June 4th, Tie Liu: An old employee of the Chengdu Evening News talks about the 13-character advertisement (Tie Liu: "Chengdu Wanbao" lao ren shuo "13 zi guanggao"),"12 June 2007, Aboluowang at http://www.aboluowang .com/news/data/2007/0612/article_23190.html (last visited 24 November 2007). For a full translation, see http://www.zonaeuropa.com/20070616_1.htm.

2. In Chinese, xiang jianqiang de 64 yunanzhe muqin zhi jing. "Three editors of Chengdu Evening News dismissed because of June 4th advertisement (Chengdu Wanbao san bianji yin "liu si" guanggao bei chezh)," Radio Free Asia (RFA), 7 June 2007, at http://www.rfa.org/mandarin/shenrubaodao/2007/06/07/chengduwang bao/, last visited 8 June 2007.

3. Id

4. I.e. the crime of dianfu guojia zhengquan zui, Criminal Law of the People's Republic of China, Art. 105 (promulgated by the National People's Congress on July 1 , 1979, revised Mar. 14, 1997). "Person who posted June 4th advertisement in Chengdu Evening News apologizes to employees" (Liu si guanggao kandengzhe xiang Chengdu Wanbao yuangong dao qian)," RFA, 4 December 2007, http://www.rfa.org/mandarin/shenrubaodao/2007/12/04/64/, last visited 5 December 2007.

5. On the significance of photographs for collective memory see Susan Sontag, Regarding the Pain of Others (New York, 2003) p. 24 f. For anecdotal evidence on the fact that a picture of the Tiananmen 1989 "tank man" may produce no sign of recognition in current Peking University students : "In 2006, the American PBS program "Frontline" broadcast a segment filmed at Peking University, many of whose students participated in the 1989 protests. Four students were shown a picture of the Tank man, but none of them could identify what was happening in the photo. Some responded that it was a military parade, or an artwork." [http://video.google.com/videoplay?docid=8633937813183253768. See http://en.wikipedia.org/wiki/Tiananmen_Square_protests_of_1989 last visited 10 December 2007 
The 13-character advertisement saluting "June $4^{\text {th }}$ mothers" in Chengdu Evening News, 4 June 2007 (last line). (c) Huang Xiaomin

thorities. While no longer liable to the blunt political condemnations of the June $4^{\text {th }}$ aftermath, some of these cases involve public acts of defiance that are just as likely to produce iconic images ${ }^{\left({ }^{(}\right)}$and phrases. ${ }^{(7)}$

This essay discusses efforts to obtain redress for historic wrongs, committed in the context of political campaigns and the suppression of popular movements, as central cases of persistent injustice ${ }^{(8)}$ originating from an historically distinct era or connected with a distinct event in history. Historic wrongs of the recent (P.R.C.) past continue to define citizen-state relationships in China today. The discussion here places the topic in the wider context of two different avenues of redress in China, one liberal and one authoritarian in nature. These two avenues are court litigation on the one hand, and the Chinese system of petitioning - or "letters and visits" - for submitting grievances to party and state authorities (including courts) on the other.

The submission of grievances belongs to an authoritarian form of political governance. For a long time, this form dominated demands for corrective reappraisal (pingfan 平反) of historic wrongs. An authoritarian conception of "wrong" or "grievance" (yuan 冤) underlying such demands does not allow complainants to question the right of the government to determine what is politically correct. But as many examples show, citizen responses to injustice are changing. An exercise of the right to free speech in order to articulate and shape the memory of these events is at the centre of many more recent citizen actions taken to address historic wrongs. Such actions include attempts to sue the government in court or to get the state to prosecute perpetrators of historic wrongs, as well as commemorative efforts such as the advertisement mentioned above. As they assert free speech rights against pressures of state censorship and social taboo, citizens are also beginning to rewrite history, challenging the party-state's traditional claim of authority to determine historical truth.

\section{Different conceptions of redress for injustice}

China has in the past few years seen intense public controversy over matters of law and legislation, justice and rights, ${ }^{(9)}$ and indeed the past one or two decades can be characterised by movement "Toward an Age of Rights," in the words of an important 1999 book. ${ }^{(10)}$ At the same time, petitioning to party-state authorities against injustice through the traditional avenue of the petitioning or "letters and visits" system ${ }^{(11)}$ has persisted. ${ }^{(12)}$ This has naturally led to the question whether the two systems can and should co-

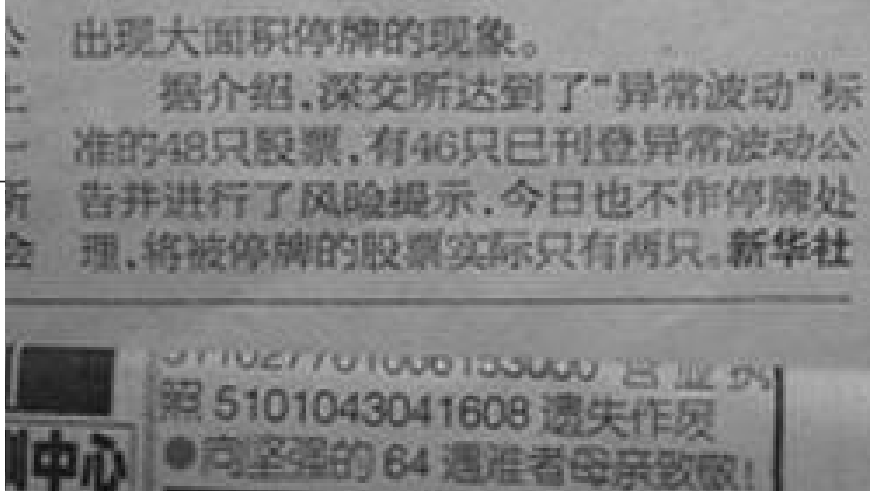

exist. The present essay comments on this question only so far as it concerns the problem of historic wrongs, by a tentative observation about the different conceptions of redress for injustice underlying court litigation and petitioning viewed as institutions. According to the view taken here, the authoritarian conception of redress for injustice, centring on the correction of wrongs by a righteous ruler, is no longer appropriate to contemporary Chinese society. At the same time, the use of court litigation for rights violations requires one to accept limitations of redress that only make sense if court practice is fair and efficient.

Few studies to date have explicitly addressed this conceptual question. The jurist and legal historian Liang Zhiping describes advantages and disadvantages of both approaches in his recent comparative analysis of the concepts of "defending rights" (weiquan 維權) and "submitting grievances" (shen yuan 伸冤 or 申冤). ${ }^{(13)}$ His discussion of a typical case of a citizen seeking redress shows that both types of in-

6. An example would be the Chongqing dingzihu case - a case of homeowners refusing to follow government orders to give way to a construction project. Even though reports and pictures were at some point banned, the pictures of the small building grotesquely perched on a clump of earth in the middle of a huge construction site, and of a woman in front of it clutching a copy of the Chinese constitution, became quickly iconic. For a collection of reports and pictures, see China Digital Times, at http://china digitaltimes.net/tag/nailhouse (last visited 10 December 2007).

7. Examples include the phrase huan women renquan and central display of the single word yuan, widely used by petitioners across the country. For a collection of photographs and accompanying narratives containing such displays, see Du Bin, The Petitioner. Living Fossil under Chinese Rule by Law (Hong Kong: Ming Pao Press 2007) e.g. at 207, 299.

8. For the characterization of historic injustice as "persistent" see Jeremy Waldron, "Redressing Historic Injustice" (2002), at http://128.100.205.43/access/jour. ihtml?lp=product/utlj/521/521_waldron.html (last visited September 2007).

9. One prominent example was discussion of the Sun Zhigang case in 2003. See Keith Hand, "Using a Law For a Righteous Purpose: The Sun Zhigang Incident and Evolving Forms of Citizens' Action in China," 45 Columbia Journal of Transnational Law 114, 159 (2007).

10. Xia Yong (editor), Toward a Time of Rights: A Perspective of the Civil Rights Development in China (Zouxiang quanli de shidai; Zhongguo gongmin quanli fazhan yanjiu) (Beijing: China University of Politics and Science Press, 1999).

11. Carl Minzner, "Xinfang: an alternative to the formal Chinese legal system," 42 Stanford Journal of International Law (2006).

12. For a comment on recent developments, see Carl Minzner, "What Has Happened to Petitioning in China Since the 2005 Xinfang Regulations?", 18 April 2007, at http://sinolaw.typepad.com/chinese_law_and_politics_/2007/04/what_has_happen.ht ml\#more (last visited 1 December 2007). Minzner doubts official claims that petitioning has declined. See also Zhao Ling, "CASS report faces up to serious state of the letters and visits system (Shekeyuan baogao zhimian xinfang yanjun shixing)," Southern Weekend, 5 April 2007, at http://www.nanfangdaily.com.cn/southnews/zmzg/2007 04050620.asp (last visited 6 April 2007). 
stitutions are used concurrently, and that conceptions of "submitting grievances" and "defending rights" play a role in both. But according to the author, not every injustice at issue in shen yuan complaints amounts to a violation of rights:

These two clusters of concepts and symbols differ most strikingly in the following way. One of them is in character negative and the other is in character affirmative. A wrong is a negation of justice, in other words an injustice. A violation of rights is a form of injustice, but injustice does not necessarily amount to a violation of rights. In the societies of the Ming and Qing dynasties, those who had been falsely accused would cry injustice, those who had been bullied would cry injustice; even those involved in property disputes and family disputes were accustomed to crying injustice when appealing to the officials, in order to get them to get involved in those disputes. They were demanding justice, ${ }^{(14)}$ but not, in doing so, asserting any rights. In fact, the state's original purpose in setting up a legal system was not to provide a codification of people's rights. It was to promote good and suppress evil, punish the treacherous and warn the uneducated.

Liang Zhiping contrasts a rights-centred with a wrongs-centred or grievances-centred conception of injustice. His argument poses some difficulties: "false accusation," "bullying," "property dispute," and "family dispute" could quite easily be subsumed under various categories of rights-related dispute; for instance, one might say that the first kind of dispute concerns a natural right not to be falsely accused by anyone. ${ }^{(15)}$ It is therefore not immediately clear why demanding justice in such cases is any different from asserting one's rights. But there is an important difference in thinking about the nature of wrongs and appropriate ways of redressing them. Different approaches are determined not only by "concepts and symbols" and their meaning, according to Liang Zhiping, but also by what he describes as institutional circumstances and the behaviour of individuals in disputes. ${ }^{(16)}$ Rights assertion, for instance in court or in public demonstrations, is associated with less supplicant, less submissive, more defiant behaviour than submitting grievances. In recent years, the idea of weiquan, "rights-defending," has inspired legal professionals dedicating themselves to public causes as well as individuals trying to protect their own rights. The character wei in weiquan conveys a sense of both "defending" and "protecting." (17) The central model of weiquan is litigation in court. Court litigation is generally associated with a strong emphasis on public controversy and open and sustained disagreement, potentially over matters of principle. By contrast, the submission of grievances is of necessity directed at persuading the authority appealed to, and the view of a just outcome as the common goal of the petitioner and the petitioned is captured in the expression shen yuan.

In terms of institutional design, Liang Zhiping observes that contemporary Chinese courts have some traits of petitioning institutions, while petitioning institutions serve some of the functions of courts. ${ }^{(18)}$ This functional overlap between the court and petitioning systems is detrimental to justice and efficiency in court practice without being in any way beneficial to the petitioning system. For instance, "final" Chinese court decisions tend to lose their finality under the current system allowing further appeals. ${ }^{(19)}$ This becomes particularly problematic if demands of justice are thought of as the right to a just decision, since that implies a right to procedural arrangements ensuring that final decisions (ideally, coherent with an existing body of law) will be taken, and that a range of procedural fairness requirements will be observed. In the absence of such institutional arrangements, a personal quest for justice may be never-ending, and indeed, may be passed down from one generation to the next. ${ }^{(20)}$ But while prolonged petitioning to challenge decisions is often lamented as a problem clogging up the already highly dysfunctional petitioning system, ${ }^{(21)}$ this behaviour is consistent with an un-

13. Liang Zhiping, "Submitting grievances and defending rights - the formation of a legal order between tradition and modernity (Shen yuan yu weiquan —- zai chuantong yu xiandai zhijian jiangou fazhi zhixu)," 21st Century Bi-monthly, December 2007, vol. 104, 11-19.

14. The expression gong dao used here can also be translated as "a just decision."

15. John Finnis in his Natural Law and Natural Rights (0xford: Oxford University Press 1980) argues for such a natural right.

16. Liang, supra note 13 at p. 14 uses the categories of fuhao, yiyi, xingdong, zhidu, and gainian (passim)

17. The character quan here stands for quanli, "rights." Weiquan can be understood as an abbreviation for weihu quanli, which translates into "defending rights" with greater precision than weiquan does. Occasionally it is also explained as weihu faquan, "protecting legal rights."

18. Liang, supra note 13 says that court litigation is a form of limited petitioning, whereas petitioning is a form of extended court litigation (sifa shi you xanzhi de xinfang, xinfang ze shi kuodale de sifa).

19. The problem of finality in petitioning is discussed by Minzner in "Xinfang: an alternative to the formal Chinese legal system," 42 Stanford Journal of International Law (2006). For an early discussion of the problem of finality in court litigation, see Liu Nanping, "A Vulnerable Justice: Finality of Civil Judgments in China," 13 Columbia Journal of Asian Law 35 (1999).

20. An expectation often expressed by petitioners. Examples are recorded, for instance, in Ai Xiaoming and Hu Jie's 2005 documentary Garden in Heaven (Tiantang huayuan).

21. On the dysfunctional nature of this system for redressing grievances, see Su Yongtong, "First national Shangfang report taken very seriously (Guonei shoufen xinfang baogao huo gaoceng zhongshi)," Southern Weekend, 4 November 2004; at http://www.nanfangdaily.com.cn/southnews/zmzg/200411041014.asp; Beijing Review, "Judicial Independence Should Come First" (interview with He Weifang), 11 October 2005, at http://www.bjreview.com.cn/En-2005/05-45-e/china-2.htm; also Zhao Ling supra note 12; Minzner supra note 19. 
Petitioners carrying banners inscribed with the character yuan (grievance).

(C) Hu Jia

derstanding of redressing wrongs as a substantive moral obligation on the part of those wronged or their relatives, as well as on the part of the ruler. Parents seeking justice for their wronged children are regarded as particularly virtuous, for instance. ${ }^{(22)}$ Their mission is accomplished only when they have persuaded the authority to which they appeal. Although a liberal system of rights-centred adjudication provides moral reasons for accepting even wrong legal decisions in some cases, ${ }^{(23)}$ this is simply unacceptable from the perspective of shen yuan, because a wrong legal decision perpetuates injustice.

The irreconcilability of the two modes of seeking justice is borne out by further analysis of the concepts involved. If we understand yuan as at its basis involving a situation that ought not to have arisen and the acceptance of which distorts moral truth, then an authority appealed to for shen yuan can recognise the facts of injustice and punish wrongdoers. A traditional understanding, however, does not require interpreting the wrong as a rights violation for which legally prescribed forms of redress and compensation are due to the right holders as a further implication of their rights. ${ }^{(24)}$ Moreover, the authorities can only provide a "just decision" in a legal dispute by "getting involved in" the dispute. Doing so is considered more in terms of an incidental intervention than as a procedure to which disputants (litigants) are legally entitled, as Liang Zhiping notes at the conclusion of his remark above. Shen yuan, submitting grievances, is therefore based on ideal assumptions that are inconsistent with the ideals underlying rights assertion and rights-centred adjudication in court.

\section{The idea of corrective reappraisal and its post- authoritarian transformation}

Pingfan (literally, "evening out and reversing") can be the aim of submitting grievances, shen yuan. At its most basic, pingfan means a corrective reappraisal. The practice of demanding reappraisal of political events that resulted in persecution is rooted in the related authoritarian belief that the ruler determines (knows) what is politically correct, and that political incorrectness deserves punishment. The logical conclusion following from these beliefs is that errors leading to political condemnation on the part of the ruler should and can only be corrected by the ruler. The use of the expression pingfan potentially extends to all individual cases in which there is a component of having been wrongly condemned by the government, and may also be used in other cases of injustice. ${ }^{(25)}$ In individual cases of historic injustice, the demand may be for reversal of a criminal conviction, compensation or other forms of material and non-material redress, or punishment of perceived culprits, and demands may reach beyond legal claims. In the reality of authoritarian political systems, the desire for reappraisal is not exclusively a matter of an authoritarian attitude on the part of the rulers and the ruled, but is reinforced by institutional arrangements ensuring that status as former political criminal has many everyday life consequences for oneself and one's family. An example of the practice of pingfan is the rehabilitation of many party officials after the Cultural Revolution (ca. 1966-1976), coupled with the general verdict that mistakes had been made by Mao Zedong. This rehabilitation was very important to the reform process begun in the 1980s. Cases still awaiting reappraisal include victims of the Anti-Rightist Movement of 1957, ${ }^{(26)}$ June $4^{\text {th }}$ victims, and Falun Gong practitioners. ${ }^{(27)}$

22. A contemporary example is the mother of Huang Jing, an alleged date rape victim who died as portrayed in Ai Xiaoming's and Hu Jie's documentary Garden in Heaven, supra note 20.

23. For a liberal argument to this effect, see e.g. Ronald Dworkin, Taking Rights Seriously, London: Duckworth 1977, pp.118-123.

24. The expression shen yuan can be translated as "submitting a grievance to higher authorities" or as "redressing a wrong." "Redressing" is perhaps thought of as a process rather than as a result. Mathews' Chinese English Dictionary, Revised American edition (Cambridge, Mass., 1975), entries for shen (nos. 5712 and 5713 ) and for yuan (no. 7719). See also The Contemporary Chinese English Dictionary (Beijing: Foreign Languages Press 2002) at p. 2354 for the translation of shen yuan as "redressing a wrong." Other expressions and their dictionary translations include bao yuan, avenging a wrong, and xue yuan, to wipe out a grievance, yuan qu de shen, to have a wrong redressed, bu bai zhi yuan, a wrong that has not been redressed, and yuan hun, the ghost of one who has suffered a wrong that has not been righted. Mathews under entry no. 7719.

25. Liang, supra note 13 at p. 15 uses the general expression pingfan yuan'an.

26. Many demands for a reappraisal accompanied commemorative events in 2007 marking the 50th anniversary of the beginning of the Anti-Rightist Movement. For petitions, see "Demanding a reappraisal of the great cases of injustice of the Anti-Rightist Movement and compensation for material and mental damages - to Party Central, The National People's Congress and the State Council (Yaoqiu pingfan youpai da yuan'an buchang wuzhi he jingshen sunshi - zhi zhonggong zhongyang, quanguo renda, guowuyuan)," 13 November 2007, at "Public Demand for 'Reappraisal' of the 'Rightists' (Gongkaixin yaoqiu wei "youpai" pingfan peichang)," 4 March 2007 at http://www.rfa.org/ mandarin/shenrubaodao/2007/03/04/youpaipingfan/; "Open Letter to the 17th Party Congress on asking to reappraise/ redress the Anti-Rightist Movements cases of injustice (Wei pingfan youpai yuan'an zhi zhonggong shiqi da de gongkaixin)," 14 0ctober 2007 at http://secretchina.com/news/gb/kanshehui/baixingnahan/2007/1014/ 215086.html; "(Liang qian Youpai zhi xin shiqi da hu kaifang yanlun zhengshi lishi)," 18 October 2007 at http://www.rfa.org/mandarin/shenrubaodao/2007/10/18/zoupai/. On the incidental rehabilitation of a lucky few, see Jerome A. Cohen, "Rightist Wrongs," Wall Street Journal, 26 June 2007, at http://online.wsj.com/article/SB118280571701 947578.html?mod=opinion_main_europe_asia.

27. For a recent discussion, see e.g. Lei Yu, Hu Wen dangju bu keneng pingfan liu si, falungong, 29 August 2007, at http://boxun.com/hero/2007/xs/67_1.shtml (last visited 29 November 2007) 


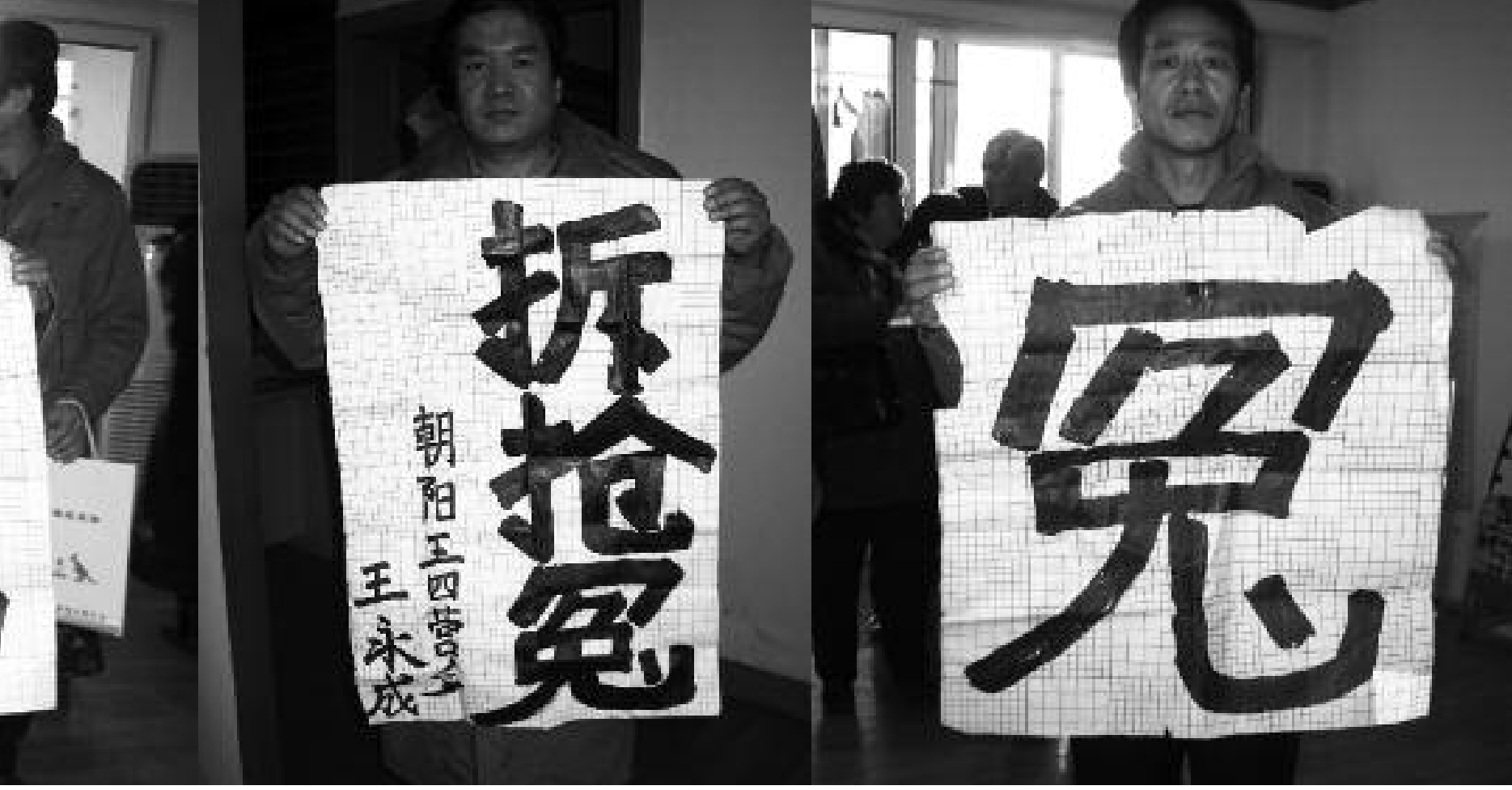

In one important respect, cases of reappraisal for wrongful political criminalization differ from general cases of submitting grievances because of the special nature of the "crime" for which a victim demanding corrective reappraisal was persecuted. From the perspective of an authoritarian conception of justice, which comprehends mutual political loyalty between the ruler and the ruled as a requirement of justice, the wrong to be redressed in such cases must consist of having been wrongly classified as an enemy of the ruler - in having been mistakenly judged to hold wrong political views. There is a (rebuttable) assumption that the ruler is correct and righteous and can therefore demand willing obedience obedience even in thought - from his subjects. There is, in other words, no room for "loyal" opposition in the authoritarian conception of pingfan, and as a result, society cannot dissociate its appraisal of government attitudes and actions in the context of particular political events from its appraisal of the nature of that government as good or bad. The only option if a government persistently shows itself to be in the wrong by denying reappraisal and rehabilitation is therefore total opposition to the government. But overthrowing the government is of course a last resort, implicit only in the grounds of legitimacy for authoritarian subjection of the ruled. As a form of shen yuan, a continued practice of demanding reappraisals therefore supports the authority of whatever government is in place. It can to a certain degree extend the legitimacy of that government backward to the time at which a government wrong was committed. ${ }^{(28)}$ Governments aware of this relationship between demands for reappraisals and legitimacy will wish to ensure a combination of supplicant submission and forgetfulness on the part of those considering themselves as having been wronged.

The case of Xie Xingding may serve as an example of the kind of retrospective submission and legitimization just mentioned. In 2005, one could find Xie in Beijing's notorious
Fengtai District "petitioning village." He was petitioning the authorities in Beijing to rehabilitate him from having been branded a rightist in 1957, which resulted in his being sent to "reeducation through labour" ${ }^{(29)}$ and then sentenced to death with two years' reprieve for counterrevolution in 1963. Xie's early release from prison in 1980 did not free him or his family from the stigma of political crime, and he had therefore been petitioning, on and off, for the past 25 years. To visitors, he would, if allowed, eagerly hand over an enormous photocopied file, compiled over the decades of his personal quest for justice, and containing his own petitions as well as administrative and court decisions made in his case and related cases.

In his petitions to various authorities, including the Supreme People's Court, Xie demanded reappraisal and hoped to be pronounced not guilty in a new court decision. Xie did not attempt, however, to argue that the "crimes" of the "Chinese People's Party" to which he had been accused of belonging had eventually became national policies under Deng Xiaoping. ${ }^{(30)}$ While mentioning in passing that being condemned as a rightist "no longer accorded with national policies," he did not try to argue that his conviction was inconsistent with basic principles in China's current law. ${ }^{(31)} \mathrm{His}$ claim was based, rather, on having been a mere "supporter," not a member, of the party in question, and on a confession having been extracted from him and others under torture. His petition did not assert adherence to good political principles (whatever these might be) so much as faithfulness to the party regardless of its policies.

In 1999, the Guizhou Provincial High People's Court had decided Xie's appeal (shensu) by ruling that there was suf-

28. Demands for pingfan share this characteristic with petitioning, xinfang.

29. On the origins of this institution in the Anti-Rightist Movement see Cohen, supra note 26.

30. See Xie Xingding, "The Call of Conscience (Liangzhi de zhaohuan)," 1 May 2005, pages 4,5 (copy on file with author). 
ficient evidence for his membership in the People's Party, while his allegations of torture were not verifiable (in this respect, the court conceded that torture would have been wrong). It concluded that Xie had in fact "joined the principal criminal Liao Shunhong in the 'People's Party' case, had actively participated in the organization of this counterrevolutionary party, had worked on recruiting new members for it, and thereby perpetrated a crime of counter-revolution." ${ }^{32}$ By 2005, one might wonder how well even Xie himself could still remember what he was petitioning about. There was only his case file, telling part of his story.

\section{Post-authoritarian} transformation of "pingfan"

However simple the authoritarian conception of pingfan may be, Chinese reality today requires a far more complex understanding of this idea and correlated practices. Some past injustices, such as those against "rightists," were inspired by ideas that have now become entirely unacceptable to the ruling party elite. As in Xie Xingding's case, the criminal political notions he was punished for having supported - for instance, greater economic freedom for individual farming households - are now celebrated as the basis for China's successful reforms. ${ }^{(33)}$ Perhaps due to the rapid ideological shifts captured in Xie Xingding's story, as well as China's general move "Toward an Age of Rights," the idea of pingfan has been employed in new ways in recent years. More liberal demands for pingfan connect the request for corrective official reappraisal with an assertion of free speech rights, thereby challenging authoritarianism as a form of governance.

As noted above, authoritarian and liberal conceptions of redress for wrongs differ in a general way, but there is also an important specific difference in the conception of the wrong of political persecution. A liberal perspective, embracing freedom of thought and freedom from censorship, carries with it the assertion that no political viewpoint can be criminalized, but at the same time assumes no right to being considered a "good subject" on authoritarian terms, or to general agreement with one's views, however loyal and correct they might be. The liberal complaint about such political condemnations as those of the Anti-Rightist Movement, the persecution of intellectuals during the Cultural Revolution, and the suppression of protests during June $4^{\text {th }}$ is not that "you got me wrong," but rather that "you had no right to persecute me on account of my views."

Despite important instances of reappraisal of political persecution granted on authoritarian terms, complaints against this kind of persecution as a violation of rights have not been successful in China up to now, for various reasons. In respect of certain historic injustices such as those of the Anti-Rightist Movement and the Cultural Revolution, there was little law in place at the time protecting the rights of citizens. This is most obviously true of the Cultural Revolution, during which the idea of lawful governance was explicitly rejected. ${ }^{\left({ }^{34)}\right.} \mathrm{A}$ mechanism explicitly for redressing state violations of the rights of citizens through administrative litigation was only introduced in 1989, and its scope is generally limited to the right of personal freedom and property rights. Constitutional rights purporting to offer any protection to citizens at the time of the political events in question ${ }^{(35)}$ are widely deemed not justiciable, even in contemporary cases of rights violations in which citizens seek protection from the courts. ${ }^{(36)}$ This is because up until now, the judiciary has largely taken the view that it has no authority to adjudicate constitutional rights cases. ${ }^{(37)}$ This does not, of course, mean that it is entirely impossible to assert such rights publicly, and to demand protection from the partystate. The open letter posted online has become a popular means of this kind of rights assertion. One example of such an action is a November 2005 letter addressed to Party Central, the National People's Congress, and the State Council, signed by more than 250 victims of the AntiRightist Campaign demanding reappraisal and at the same

31. Such as the right to free speech (Constitution of the People's Republic of China (revised 2004), Art. 5. It would of course be difficult to be successful with this argument since constitutional rights continue to be regarded as unjusticiable. See supra note. 37.

32. Id (file excerpt) p. 75

33. "Political criminal" (zhengzhifan) was a technical expression in use well into the 1980s. See also 1979 Criminal Law of the People's Republic of China (old version, amended in 1997), Chapter One, "Crimes of Counterrevolution" at http://www.lawinfochina.com/ law/display. $a s p ? d b=1 \& i d=3 \&$ keyword=criminal\%20law (last visited 24 November 2007).

34. For a political statement characteristic of that time, see Xinhua News, "Completely Smash the Feudal, Capitalist, and Revisionist Legal System" (1968), Vol.2 No. 4 (196970) Chinese Law and Government 7.

35. With the exception of China's 1975 Constitution, only in force until 1978, all P.R.C. Constitutions contained fundamental rights catalogues. The 1975 Constitution mentioned "speaking out freely, airing views fully, holding great debates and writing dazibao" as forms of "carrying on socialist revolution." Hua Sheng, "Big Character Posters in China: A Historical survey," 4 Journal of Chinese Law 234 (1990) at p. 242.

36. For a discussion of this view see Keith Hand, supra note 9

37. There have been important exceptions, such as the case of Qi Yuling et al. v. Chen Xiaoqi, decided by Zhaozhuang Intermediate People's Court, Shandong, in 2001, after obtaining a written instruction from the Supreme People's Court. See Huang Songyou, "The judicialisation of the constitution and its further implications - a discussion starting from a Supreme People's Court's response issued today (Xianfa sifahua jiqi yiyi - cong zuigao renmin fayuan jintian de yige 'pifu' tanqi)," 13 August 2001, available at http://www.gongfa.com/huangsyxianfa sifahua.htm; Wang Zhenmin, China's Unconstitutionality Review System (Zhongguo weixian shencha zhidu, Beijing: Chinese University of Politics and Law Press 2004), p. 206. 
Protesters in the "petitioner's village"

in Beijing in 2001, carrying a banner inscribed with the character yuan (grievance).

( ) Liu Zhengyou time asserting their right to compensation for the violation of numerous rights contained in the 1954 P.R.C. Constitution. ${ }^{(38)}$ Another petition earlier this year went a step further by calling upon the leadership to "take a correct view of history and open up debate" (emphasis added). ${ }^{(39)}$ The minimum demand of the "rightists," according to one interviewee, was that the party-state allow genuine freedom of the press. In addition, he said, there ought to be a reappraisal, and compensation should be paid to the victims of the Anti-Rightist Movement. ${ }^{(40)}$

In individual cases in which redress for historic injustice is sought, the mutually exclusive attitudes of submissiveness and defiance may alternate. An example is the case of Zhou Guocong, a June $4^{\text {th }}$ student protestor whose parents sought justice on his behalf. Fifteen-year-old Zhou had been detained in Chengdu at the time of the 1989 protests. He died in police custody, and while no autopsy was performed, photographs later posted on the Internet showed bruises and cuts on his body. ${ }^{(41)}$ His parents had for 17 years demanded an investigation into the circumstances surrounding his death, as well as punishment of those found responsible. When it was learned in May 2006 that they had been granted a government payment called "hardship support," a Western news service promptly reported it as "the first time a victim had been compensated" (emphasis added). ${ }^{(42)}$ But other observers disagreed about the significance of the case. Eventually it was learned that the parents, extremely impoverished at the time, had been asked for a "written promise to stop suing the government" (xisu baozhengshu 息訴保證書) but that after receiving the payment, they had reneged on their promise. Discussion of this case was contentious: while some pointed out that the government had evaded an admission of wrongdoing implicit in the word "compensation" (peichang), and mentioned other cases in which attempts had been made to "buy off" petitioners, ${ }^{(43)}$ others seemed to see in this payment a first step toward reappraisal. The rights defender Guo Feixiong, taking the latter view, also said that in a case like this, the parents' promise to stop suing the government could not be considered binding. ${ }^{(4)}$

Zhou Guocong's case illustrates, first, the difference between demands for reappraisal and rights assertion: a "compensation" payment from the state would have been perceived as a modern and rights-centred form of providing redress (for state tort). Second, the case also shows that even as an explicit compensation for an acknowledged rights violation, a mere payment could not have satisfied Zhou's parents. Nor could a mere meting out of punishment, dissoci-

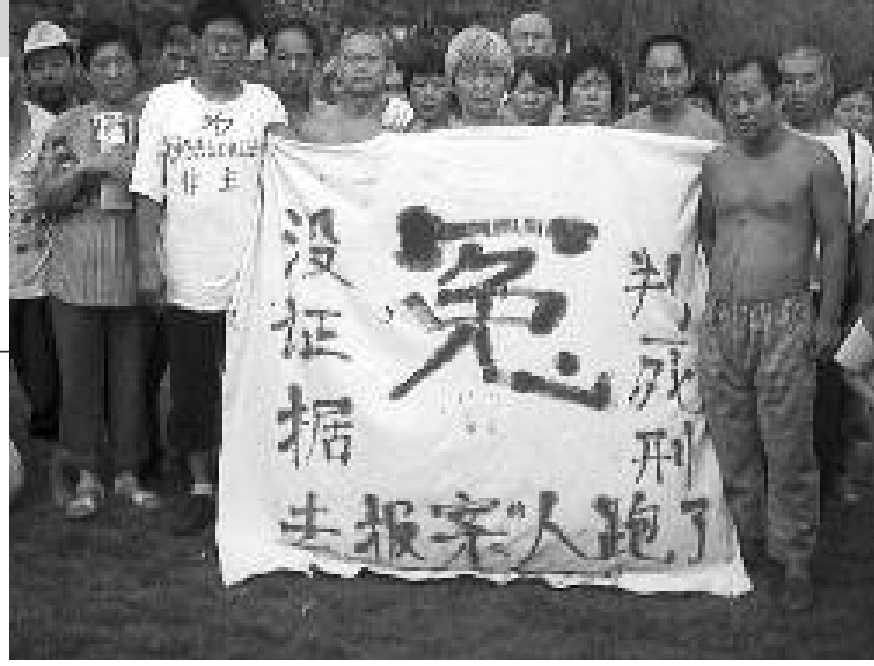

ated from a criminal trial process, have satisfied them. To judge by available reports, their demands included, crucially, a call for an open investigation to determine the circumstances of their son's death. ${ }^{(45)}$ That discovery and official recognition of the facts surrounding Zhou Guocong's death would very likely have a complexity far exceeding a statement of civil liability requiring the state to pay a certain amount of compensation to Zhou's parents. It is possible that not even a criminal investigation and trial process, if carried out, would convince the parents that justice had been done. Although it would likely throw light on the detailed circumstances for their son's death and suggest who was culpable, an appropriate criminal process would have to take into account the possibility that higher authorities authorized the investigation, if not the beating or killing, of Zhou Guocong for a crime of counter-revolution under China's 1979 criminal code. ${ }^{(46)}$ Inevitably, too, a criminal process would raise but probably not answer questions of responsibility for the "political" decision to brutally suppress the 1989 protests. ${ }^{(47)}$ In that sense, even the best possible outcome of a court-based process to provide redress based on liberal principles would prove unsatisfactory.

38. The petition mentions the right to free speech (Art. 17) and cultural rights (Art 95) as well as the right to be compensated in the case of violation of these constitutional rights (Art 97). See http://cdp1998.org/details.asp?detailsid=2886.

39. Ding Xiao, "Two thousand rightists send letter to 17th Party Congress, calling for an opening up of debate and a correct view of history (Liangqian youpai zhixin shiqi da hu kaifang yanlun zhengshi lishi)," 18 0ctober 2007, at http://www.rfa.org/mandarin/ shenrubaodao/2007/10/18/zoupai/ (last accessed 10 December 2007).

40. Chen Juxiao, as quoted $i d$.

41. At the website http://www.64tianwang.com, which collects and disseminates information on June 4th victims.

42. "Reuters: China payment for 1989 victim a first: activist", 21 May 2006, at http://today.reuters.com/news/articlenews.aspx?type=worldNews\&storyid=2006-0430T073221Z_01_PEK143037_RTRUKOC_0_US-CHINA-COMPENSATION.xml, last visited 24 November 2007

43. Ye Ning as quoted in Shen Hua, "Are support payments an ideal way of resolving the June 4th problem? (liu si nanshu huo buzhu shifou shijiejue liu si wenti de lixiang mosh)," RFA, 21 May 2006, at http://www.rfa.org/mandarin/shenrubaodao/2006/ 05/01/6.4/; Ding Zilin as quoted in CRD, “June 1: 'Tiananmen Mothers' leader Ding Zilin urges remembering '6.4,' " 2 June 2006, at http://crd-net.org/Article/Class9/ Class10/200606/20060602000017_1317.html.

44. Ding Xiao, supra note 38.

45. See reports supra note 43.

46. Note 31.

47. An account of how this decision was formed and who took it is provided in Andrew Nathan and Perry Link (editors), The Tiananmen Papers (London, 2001). 


\section{Conclusion: the significance of official attitudes to historic wrongs}

The discussion here has shown that historic wrongs pose challenges for both liberal and authoritarian systems. Liberal systems burdened by historic injustice can try to cope by allowing or even encouraging open discussion of historic wrongs, and by letting the judiciary redress wrongs on a case-by-case basis. ${ }^{(48)}$ Authoritarian governments can make corrective reappraisals of historic wrongs. Chinese citizens request such reappraisals through the shen yuan form of appeal on an implicit expectation that the authorities will reach a correct viewpoint and find appropriate responses to their demands; ${ }^{(49)}$ it may be simplistic, however, to suggest that common people believe in the integrity of the central government while considering local governments corrupt. ${ }^{(50)}$ The fact that petitioners, in particular, have limited opportunities to question the system they are using does not necessarily mean that they believe the system to be good. Indeed, many petitioners show great dissatisfaction with being forced by China's legal and political system to go through the motions of a clearly dysfunctional process. ${ }^{(51)}$

However, even going through the motions of such a system of redress can, at the very least, prompt public declarations of faith in the future correction of wrongs, as in the case of netizen's comments posted in May 2007 on a BBC news (Chinese Language) website soliciting views on the desirability of pingfan for June $4^{\text {th: }}$

I trust that in the future not only the Communist Party but the entire Chinese nation will reach a correct viewpoint on these events. That is my faith in the Communist Party and the nation. (...) Has not enough of the blood of the students been already spilt? (We must not look for facile excuses. They ought to be living well, as well as you are living now. Why was it them who had to die?)

$$
\text { Chengcheng [Sincerity], China }{ }^{(52)}
$$

This orthodox confirmation of the faith exacted from authoritarian-minded subjects puts great pressure on a government and society expected to live up to it. In a wrongs-centred culture, the pressure may be particularly great when obtaining redress for wrongs becomes a moral obligation passed on from one generation to the next.

The liberal, rights-centred transformation of pingfan requests, reflected in citizens' assertion of the right to free speech and requests to allow for free debate of historic injustices, can in some ways increase pressure on a government by posing a challenge to political authoritarianism. The mere public discussion, not to mention admission, of some of the historic wrongs burdening China's present could undermine the premises on which its current government is built. The resulting dilemma is reflected in other comments on the BBC website mentioned above, ${ }^{(53)}$ with some suggesting that a reappraisal of June $4^{\text {th }}$ would make little difference, but others arguing that true reappraisal would result in a change of China's political system. Most commentators seem to understand the question of reappraisal as an indirect question about the nature or legitimacy of the current political system or government. Relatively little comment focused on the question of whether the government was justified in its suppression of the June $4^{\text {th }}$ protests:

It is irrelevant if June $4^{\text {th }}$ is reappraised or not. It is simply a fact that the students at the time had the right ideas but adopted wrong methods. Everybody may consider this for themselves: do they want the country to be plunged into chaos, do they want civil war, or do they hope to live in peace and quiet, while the political environment changes gradually?

A contributor from China

It was so long ago. Does it have to be raised again? For the vast majority of Chinese people, reappraisal would not have the slightest meaning. Old Jiang

48. See above at p. 8 infra note 23 on the treatment of wrong decisions in liberal legal systems.

49. Thus, petitioner Xie and others in Beijing's petitioning village with a multitude of different grievances seemed as ready to assert that the government was hei, black or bad, as they were willing to keep on appealing to it. Visit to petitioning village, 24 May 2005.

50. Minzner, supra note 11, at p. 159 quotes Yu Jianrong's study, showing that while 94.6 percent of newly-arrived petitioners in Beijing believed central authorities would welcome them, this rate had dropped to 39.3 percent among those who had been there a week or longer.

51. References supra note 21. Dissatisfaction found expression, for instance, earlier this year in a collective letter signed by over a thousand petitioners suggesting the abolition of the petitioning system and demanding constitutional government and the creation of a constitutional court. Fang Yuan, "Joint letter by more than 1,000 petitioners attracts central authorities' attention (Shang qian fanmgmin lianming xinjian yinqi zhongyang zhongshi)," RFA, 21 March 2007, at http://www.rfa.org/mandarin/shenrubaodao/ 2007/03/21/fangmin. The letter was called "Suggestions to the Party, the People's Congress and the Consultative Congress (Zhongguo fangmin zhi zhonggong zhongyang renda zhengxie de jianyishu)."

52. BBC Chinese, "Do you agree with the suggestion to reappraise June 4th?(Ni zancheng pingfan liu si de jianyi ma)," 21 May 2007, at http://news.bbc.co.uk/chinese/ simp/hi/newsid_3780000/newsid_3780200/3780229.stm.

53. Id. Hundreds of contributions were posted at this website. The following is a selection trying to give an impression of the spectrum of opinions 
The activist Hu Jia wearing a T-shirt that commorates the arrival of tanks on Tiananmen square in 1989. Hu Jia was detained on 27 Decmber 2007 and charged with subversion in January 2008.

() Teng Biao

Reappraisal of June $4^{\text {th }}$ is a requirement of higher justice. I honour Dr. Jiang's righteous action! ${ }^{(54)}$

Anonymous, China

The day on which the Communist Party calls itself Democratic Party, that day we will have true pingfan.

A common person, England

Reappraisal is a matter to be decided by the Chinese people; we must under no circumstances allow foreign powers to meddle.

Greater China’s Elite Trouble-Maker, Europe

June $4^{\text {th }}$ will certainly be reappraised one day. And so will the Falun Gong. In Taiwan, no one nowadays still says that [the government's action in] the $28 \mathrm{Feb}$ ruary Incident was right; it is always referred to as "a tragedy"...when the government has made a mistake, it must apologise. Dr Jiang Yanyong represents China's conscience!

Old Bao, Taiwan

A reappraisal of June $4^{\text {th }}$ is difficult. When the people demand democracy from an autocratic government, it is like asking the tiger for his skin. If it is really possible to get a reappraisal, then perhaps more trouble will result. Don't those "democracy fighters" abroad ask to be allowed to return home so they can continue their work for democracy? How could the Party allow that? They are really too naive.

The Gossiper, Hong Kong

We are an autocratic country, so when the government is threatened, they must kill without mercy. There is nothing to discuss here.

$$
\text { Zhang Jianguo, China }
$$

We Chinese have already become used to stupor and slavish-mindedness. Our brains have a reduced capacity for memory. If we can live from day to day, eat, and breathe, that's already not too bad. What does it matter if there is reappraisal or not? Oh, those children died too cruel deaths! Li Zhonghua, China

According to the view taken here, requests for reappraisal are important because of the significance of official attitudes to historic wrongs. If an authoritarian state offers no publicly recognized grounds for condemning certain types of injustice, independent of the possibility of corrective reappraisal at the discretion of the government, the historic wrong acquires no public meaning in that society. But as long as such historic injustice is remembered by some, attitudes to certain fundamental wrongs committed in the name of this state are as much part of its normative foundation as the most basic legislative commitments of a state under the rule of law. If the state announced a reversal of its judgement about June $4^{\text {th }}$, people would react with approval or disapproval, by making specific requests for redress in individual cases, and very possibly also by demanding justice - pingfan - in cases unrelated to June $4^{\text {th }}$. Present efforts on the part of many people to preserve, revive, discuss, and disseminate the memory of China's historic wrongs are therefore as much an attempt to challenge the authoritarian traits of the political system as they are efforts to obtain redress for these wrongs. Under these conditions, the proper form of redress for historic wrongs is neither a new version of authoritative corrective reappraisal nor compensation or punishment in relation to individual cases. Rather, it must consist of an opening-up of public and collective debate of the wrongs in question while memories of these wrongs and calls for reappraisal persist. •
54. In March 2004, Jiang Yanyong, a doctor who had gained respect by his exposure of the initially covered-up 2003 SARS crisis in Beijing, demanded reappraisal for June 4th and Falun Gong in an open letter addressed to the highest party-state leadership. See BBC Chinese, "Jiang Yanyong suggests reappraisal of June 4th (Jiang Yanyong jianyi we liu si pingfan)" at http://news.bbc.co.uk/hi/chinese/news/newsid_3542000/35421271.stm (last visited 10 December 2007). 